\title{
Association between IL-17 and $\lg A$ in the joints of patients with inflammatory arthropathies
}

Ricardo Javier Eliçabe ${ }^{1,2}$, Juan Eduardo Silva ${ }^{1,2}$, Mabel Noemí Dave ${ }^{1,2}$, María Gabriela Lacoste ${ }^{1,2}$, Héctor Tamashiro ${ }^{3}$, Rodrigo Blas ${ }^{4}$, Alicia Munarriz ${ }^{5}$, Gabriel Adrián Rabinovich ${ }^{6,7}$ and María Silvia Di Genaro ${ }^{1,2^{*}}$

\begin{abstract}
Background: Hyperactive secretion and pathogenic effects of interleukin (IL)-17 and IgA have been detected in different arthropathies. Recent evidence has revealed that $T_{H} 17$ cytokines regulate mucosal IgA secretion. However, it is unknown whether and how IL-17 mediates synovial IgA production. Here we aim to investigate the connection of synovial IL-17 with IgA production in the joint.

In this study we included synovial fluids (SF) from patients with rheumatoid arthritis (RA; $n=66$ ), spondyloarthritis $(\mathrm{SpA} ; n=18)$ and osteoarthritis $(\mathrm{OA} ; n=36)$. The levels of IL-17, IL-6, transforming growth factor (TGF)- $\beta_{1}, \mathrm{~B}$-cellactivating factor of the TNF family (BAFF) and anti-lipopolyssacharide (LPS) immunoglobulin (Ig)A were investigated by enzyme-linked immunosorbent assay (ELISA). Total IgA was measured by radial immunodiffusion assay. Synovial fluid-derived mononuclear cells (SFMC) were stimulated with bacterial antigens or SF-conditioned media, and cytokines and $\lg$ A were analyzed in the supernatants.

Results: IL-17, IL-6 and TGF- $\beta_{1}$ were increased in SF from both RA and SpA compared with OA patients. Concentration of IL-17 correlated with the disease activity score (DAS)-28, IL-6 and anti-LPS IgA levels. Bacterial-stimulated SFMCs from RA and SpA patients secreted higher IL-17 than vehicle-stimulated SFMCs. Conditioned media with SF containing IL-17 induced anti-LPS IgA production by SFMCs which was independent of IL-6 activity. Concentrations of synovial TGF- $\beta_{1}$ and BAFF correlated with anti-LPS and total IgA levels, respectively. Blockade of IL-17 decreased the production of TGF- $\beta_{1}$ and anti-LPS IgA by SF-stimulated SFMCs.
\end{abstract}

Conclusions: This study reports a connection between IL-17 and IgA secretion in the joint. In addition, it demonstrates that enterobacterial antigens trigger synovial IL-17 production, and that TGF- $\beta_{1}$ and BAFF may mediate the effect of IL-17 on IgA production. This circuit may contribute to the pathogenesis of inflammatory joint diseases.

Keywords: Interleukin-17, Immunoglobulin A, Synovial fluid, Transforming growth factor, B-cell activating factor of the TNF family

\footnotetext{
*Correspondence: sdigena@unsl.edu.ar

'Division of Immunology, Faculty of Chemistry, Biochemistry and Pharmacy,

National University of San Luis, Ejército de los Andes 950, San Luis, Argentina

${ }^{2}$ Laboratory of Immunopathology, Multidisciplinary Institute of Biological

Investigations - San Luis (IMIBIO-SL), National Council of Scientific and

Technical Investigations (CONICET), Ejército de los Andes 950, San Luis 5700,

Argentina

Full list of author information is available at the end of the article
} 


\section{Background}

Mucosal surfaces serve as a protective barrier against most pathogens. These surfaces are protected by a first-line defense mediated by immunoglobulin A (IgA) [1]. Moreover, it is also known that $T$ helper $\left(T_{H}\right) 17$ cells are more abundantly present at the mucosal surface of the intestine, compared with other T-cell subsets [2]. Accumulating evidence has demonstrated that $\mathrm{T}_{\mathrm{H}} 17$ cells contribute to intestinal homeostasis by regulating intestinal IgA secretion supporting a link between intestinal T-cell function and IgA production $[3,4]$. Less is known about the potential role of $\mathrm{T}_{\mathrm{H}} 17$ cells for IgA induction in the joint, though chronic activation of $\mathrm{T}_{\mathrm{H}} 17$ can cause arthropathies $[5,6]$ and hyperactive IgA synthesis occurs in many types of inflammatory joint diseases [7-10].

In spite of the long-standing assumption that infectious agents and their products may influence the development of osteoarticular diseases $[11,12]$, our understanding of the intricate connections linking bacterial components with inflammatory arthropathies is still limited. Rheumatoid arthritis (RA), one of the most common autoimmune osteoarticular diseases, is characterized by synovial inflammation and hyperplasia, autoantibody production, cartilage and bone destruction and systemic disorders mainly driven by pro-inflammatory cytokines and matrix-degrading enzymes [13]. Infectious agents and their products have been largely linked with RA although the precise mechanisms implicated in this complex relationship is not fully understood $[11,12,14]$. Elucidation of the pathogenic mechanisms that perpetuate RA will open the possibility of better disease management and rational control of immune dysregulation [13]. Spondyloarthritis $(\mathrm{SpA})$ is the second most prevalent form of chronic inflammatory arthritis (prevalence $0.5-1.5 \%$ ) that mainly affects young adults [15]. SpA has been traditionally subdivided into subtypes including ankylosing spondylitis (AS), psoriatic arthritis (PsA), reactive arthritis (ReA), arthritis/spondylitis associated with inflammatory bowel disease (IBD), and undifferentiated SpA (uSpA) [16]. However, evidence suggests that SpA is a single disease with a heterogeneous phenotype [17]. Although the etiology of SpA remains obscure, it has demonstrated a strong association with environmental factors including pathogenic intestinal microbes [18]. However, whether enterobacterial antigens trigger synovial IL-17 in RA and SpA is still uncertain.

It is known that transforming growth factor (TGF)- $\beta_{1}$ has a unique role in driving IgA isotype switching [19], and is also critical for $\mathrm{T}_{\mathrm{H}} 17$-cell differentiation [20]. It is also known that IL-6, a major factor for the differentiation of naive CD4 T cells into Th17 cells [21], plays a key role in B-cell proliferation and antibody secretion [22]. However, there is no evidence indicating that TGF- $\beta_{1}$ or IL-6 together with IL-17 have a role for IgA generation in joint. Ultimately, B- cell-activating factor of the TNF family
(BAFF) has been recognized as a cytokine that induces IgA class switching by activating B cells [23]. Interestingly, IL-17 has also been recently shown to synergize with BAFF to increase the frequency of autoantibodies, and high BAFF levels have been considered a measurement of B-cell dysfunction in autoimmune diseases [24].

In the present study, we aimed to examine the role of IL-17 in IgA production in the joint. We used synovial fluids (SF) containing different cytokines rather recombinant cytokines in order to recreate the pathophysiologic microenvironment of the joints during ongoing inflammatory diseases. These findings identify pathways by which IL-17 mediates induction of synovial IgA responses during inflammatory arthropathies.

\section{Methods}

\section{Patients}

Synovial fluids (SF) were obtained from 66 RA, 18 SpA and 36 osteoarthritis (OA) patients from San Luis, Argentina. Since OA is not associated with infections, these patients were considered a control group. The RA and SpA patients met the American College of Rheumatology (ACR) [25] and the European Spondyloarthopathy Study Group (ESSG) criteria [26], respectively. Table 1 shows the demographic features of patients. To enroll in the study, patients in all groups required knee effusion of SF. Age, sex and disease duration were recorded (Table 1). Fifty six RA patients were classified as late stage disease according to the ACR criteria [25]. Eight patients with early SpA were categorized as having disease of less than 6 month-duration (Table 1). The 28-joints disease activity score (DAS28) was used as a measure of disease activity in RA [27]. The medium DAS28 of the RA patients was 4.64 \pm 1.6 (range: $2.42-7.1$ ). The $95 \%, 44.5 \%$ and $21.4 \%$ of RA, $\mathrm{SpA}$ and OA patients, respectively were positive for Creactive protein (CRP). The $\mathrm{SpA}$ group included patients with AS (1), PsA (5), ReA (3), IBD (1) and uSpA (8). The current medications were recorded and included: nonsteroidal anti-inflammatory drugs in 39 patients with RA and 10 with SpA; methotrexate in 40 patients with RA and 11

\begin{tabular}{|c|c|c|c|c|}
\hline Disease & $\begin{array}{l}\text { Patient } \\
\text { number }\end{array}$ & $M: F$ & $\begin{array}{l}\text { Medium age, } \\
\text { years } \\
\text { (range) }\end{array}$ & $\begin{array}{l}\text { Medium duration } \\
\text { of disease, years } \\
\text { (range) }\end{array}$ \\
\hline RA & 66 & $12: 54$ & $\begin{array}{l}55 \\
(20-74)\end{array}$ & $\begin{array}{l}8 \text { ( } 3 \text { months- } 30 \text { years) } \\
85 \% \text { chronic phase } \\
\text { (>1 year) }\end{array}$ \\
\hline SpA & 18 & $14: 4$ & $\begin{array}{l}33 \\
(12-59)\end{array}$ & $\begin{array}{l}4 \text { ( } 2 \text { months }-17 \text { years) } \\
55 \% \text { chronic phase } \\
\text { (>6 months) }\end{array}$ \\
\hline OA & 36 & $11: 25$ & $\begin{array}{l}61 \\
(42-83)\end{array}$ & - \\
\hline
\end{tabular}

$R A$ rheumatoidarthritis, $S p A$ spondyloarthritis, $O A$ osteoarthritis, M:F male:female 
with SpA; leflunomide in 16 patients with RA; hydroxychloroquine in 12 patients with RA; sulfasalazine in 6 patients with RA and 8 with SpA; anti-TNF in 6 patients with RA and 1 with $\mathrm{SpA}$; prednisone in 24 patients with RA. Combined medication was used in the majority of the patients. Ten patients with RA had no treatment at the moment of study enrolment since SF drainage was required in their first visit to the rheumatologist.

\section{Ethical aspects}

The study was approved by the Ethics Committee of the National University of Cuyo, Mendoza, Argentina. Informed consent was obtained from all patients included in the study. The principles of Helsinki Declaration 1975/83 were followed.

\section{Synovial fluid preparation}

SF was aspirated from knee joints and mixed immediately with $50 \mathrm{IU} / \mathrm{ml}$ heparin. The volumes of aspired fluids were 5-30 ml. SF of RA and SpA patients were classified as inflammatory since all of them had more than 2000 cells/ $\mathrm{mm}^{3}$; in contrast, OA patients had non-inflammatory SF (less than 2000 cells $/ \mathrm{mm}^{3}$ ) $[28,29]$. For cytokine and antibody analysis, samples were centrifuged at $250 \mathrm{x} \times \mathrm{x}$ for $10 \mathrm{~min}$ and the supernatants were stored at $-20^{\circ} \mathrm{C}$.

\section{Cytokine determination by enzyme-linked immunosorbent} assay (ELISA)

IL-17, TGF- $\beta_{1}$ and IL-6 were determined in SF using commercial capture ELISA kits (eBioscience, San Diego, CA, USA), according to the manufacturer's instructions. The limits of detection for the above-mentioned assays were $4 \mathrm{pg} / \mathrm{ml}$ for IL-17, $2 \mathrm{pg} / \mathrm{ml}$ for IL- 6 and $8 \mathrm{pg} / \mathrm{ml}$ for TGF$\beta_{1}$. The SF with levels of these cytokines higher than the limit of detection was considered positive in the frequency analysis. BAFF was determined by ELISA kit (Antigenic America, Huntington Station, NY, USA) which was kindly provided by Dr. Adriana Gruppi (National University of Córdoba, Argentina).

\section{Enterobacterial antigen preparations}

Yersinia enterocolitica O:8, strain WA-314 (kindly provided by Dr Kapperud, Department of Bacteriology, Oslo, Norway) was used for heat killed Yersinia (HKY) preparation, which consisted in a twice autoclaved bacterial suspension $\left(1 \times 10^{10}\right.$ bacteria $\left./ \mathrm{ml}\right)$. The absence of bacterial growth in HKY was tested by plating on Mueller-Hinton agar and incubation at $26{ }^{\circ} \mathrm{C}$ for $48 \mathrm{~h}$. Lipopolysaccharide (LPS) was obtained as previously described [30].

\section{Synovial anti-enterobacterial $\lg A$ and total $\lg A$}

Multiwell plates were coated with $100 \mu \mathrm{l}$ per well of $10 \mu \mathrm{g} / \mathrm{ml}$ LPS in $0.15 \mathrm{M}$ phosphate-buffered saline (PBS) $\mathrm{pH} 7.2$ at $4{ }^{\circ} \mathrm{C}$ overnight. After incubation with 1:50 diluted SF, bound antibodies were demonstrated by reaction with goat anti-human IgA and peroxidase-conjugated rabbit anti-goat IgG (Sigma, St. Louis, MO, USA) followed by the addition of the enzyme substrate $\left(\mathrm{H}_{2} \mathrm{O}_{2}\right)$ and chromogen O-phenylendiamine (Sigma). Optical density (OD) was measured at $490 \mathrm{~nm}$ in an ELISA reader (BioRad, Hercules, CA, USA). Total IgA levels in SF were determined by radial immunodiffusion assay (Diffu-Plate kit, Biocientífica, Buenos Aires, Argentina)

Assessment of IL-17, TGF- $\beta 1$ and anti-LPS IgA in stimulated mononuclear cells from $\mathrm{SF}$

SF mononuclear cells (SFMC) were obtained using FicollHypaque (Histopaque 1077, Sigma). Cells $\left(2 \times 10^{6}\right.$ cells/ well) were cultured in RPMI 1640 medium (Hyclone, Logan, UT, USA) with 10\% fetal bovine serum (FBS) (Sigma), and stimulated with $10^{7}$ or $10^{8}$ bacteria/ml of HKY and incubated at $37{ }^{\circ} \mathrm{C}$ in $5 \% \mathrm{CO}_{2}$. Supernatants were collected after $72 \mathrm{~h}$ for determination of IL-17 using a commercial ELISA kit (eBioscience). In addition, SFMC were incubated for $96 \mathrm{~h}$ with media conditioned with different dilutions of SF containing IL-17; then, TGF- $\beta_{1}$ or anti-LPS IgA were measured by ELISA. To analyze the role of IL-6 in this effect, cells were incubated in vitro with pharmacologically relevant concentrations of the anti-IL-6 receptor antagonist tocilizumab (TCZ) $(200 \mu \mathrm{g} / \mathrm{ml}$, Roche Pharma, Grenzach-Wyhlen, Germany) [31]. To analyze the effect of synovial IL-17, the cells were stimulated with SF in presence of the anti-IL-17 $(100 \mu \mathrm{g} / \mathrm{ml}$, Secukinumab, Novartis Argentina SA, Buenos Aires, Argentina).

\section{Statistical analysis}

Differences in the amounts of cytokines or IgA in RA, $\mathrm{SpA}$ and OA patients were compared by using one-way analysis of variance (ANOVA) followed by Tukey's multiple comparison test. Two variables were compared by unpaired Student's $t$ test. Differences in the frequencies of SF with detectable level of cytokine (positive SF) in each group of patients were analyzed by Fisher's exact test. Correlations between two variables were examined by Spearman's analysis. A $P$ value less than 0.05 was considered as statistically significant. All analyses were performed using GraphPad Prism 5 software (GraphPad Software, San Diego, CA, USA).

\section{Results}

Synovial IL-17, IL- 6 and TGF- $\beta_{1}$ production in patients with RA and SpA

Since IL-17 has been associated with the pathogenesis of RA and SpA [32, 33], we first studied this cytokine in SF from RA and SpA in comparison with OA patients. Next, we analyzed the cytokines TGF- $\beta_{1}$ and IL- 6 that in combination are required for $\mathrm{T}_{\mathrm{H}} 17$ development [21]. The frequency of SF with detectable levels of each cytokine was 
also compared. We found a higher number of patients with detectable synovial IL-17 in RA and SpA compared to OA (62\% and 59\%, respectively versus $5.5 \%)(P<0.0001$ compared with $\mathrm{OA}$ for both comparisons). Of note, the IL-17 median concentration was significantly higher in SF from RA or SpA compared to OA patients $(P<0.0001)$ (Fig. 1a). We next examined whether an association exists between the levels of IL-17 and disease activity in RA. We found that synovial production of IL-17 correlated with RA disease activity as measured by DAS28 $(r=0.4, P<$ 0.05) (Fig. 1b). The determination of TGF- $\beta_{1}$ revealed similar differences as those observed for IL-17 as higher percentage of RA or SpA patients had detectable levels of TGF- $\beta_{1}$ in their SF $(P<0.0001$ compared with OA for both comparisons) and the median values of this cytokine were higher in SF from both RA and SpA patients $(P<$ $0.0001 \mathrm{RA}$ vs $\mathrm{OA}$, and $P<0.01 \mathrm{SpA}$ vs OA) (Fig. 1c). Furthermore, a high percentage of RA, SpA and OA patients had IL-6 in their SF (98\%, 93\% and 90\%, respectively), while the median concentration of this cytokine was significantly elevated in RA and SpA patients compared with OA patients $(P<0.0001$ for both comparisons) (Fig. 1d).
Remarkably, when we analyzed the relationships between the different cytokines, we observed a positive correlation between IL-6 and IL-17 in SF from RA and SpA patients $(r=0.3 ; P<0.01)$ (Fig. 1e).

\section{Secretion of IL-17 by SFMCs from patients with RA and SpA after stimulation with enterobacterial antigens and anti-enterobacterial IgA response}

We investigated a possible causative link between bacterial antigens and synovial IL-17 production. Therefore, we evaluated the effects of stimulating with HKY in SFMC obtained from RA and SpA patients. We found that SFMC from RA and SpA patients secreted significantly higher amounts of IL-17 following stimulation, and this effect was found to be dose-dependent when different HKY concentrations were used (Fig. 2a). Consistent with our previous findings demonstrating a correlation between IL-17 and IL-6, we found that IL- 6 was also induced by HKY-stimulation of SFMC (Fig. 2b). In presence of TCZ, an inhibitor of IL- 6 function, although IL-6 was secreted (Fig. 2b), IL-17 production by HKYstimulated SFMC significantly decreased (Fig. 2c). These

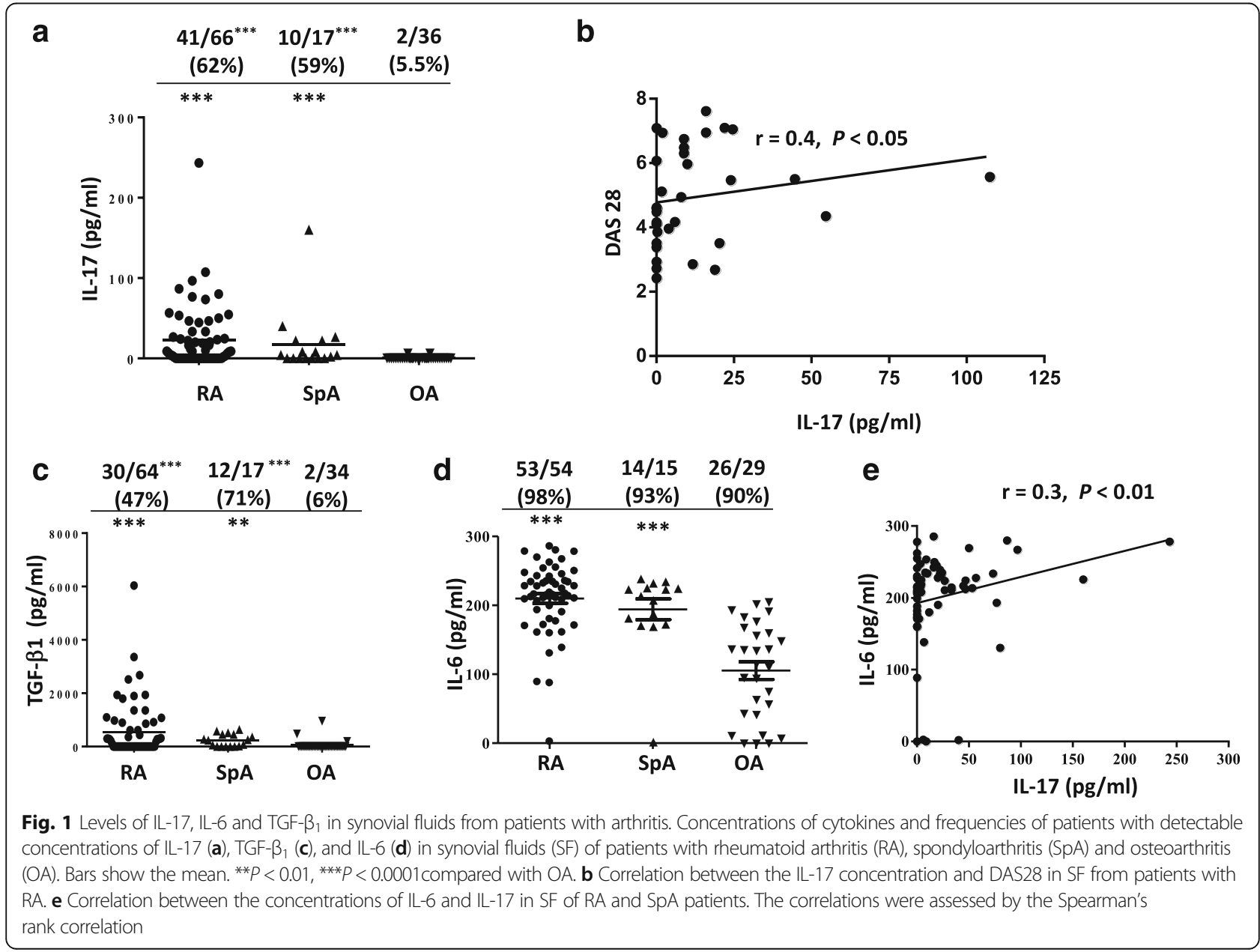



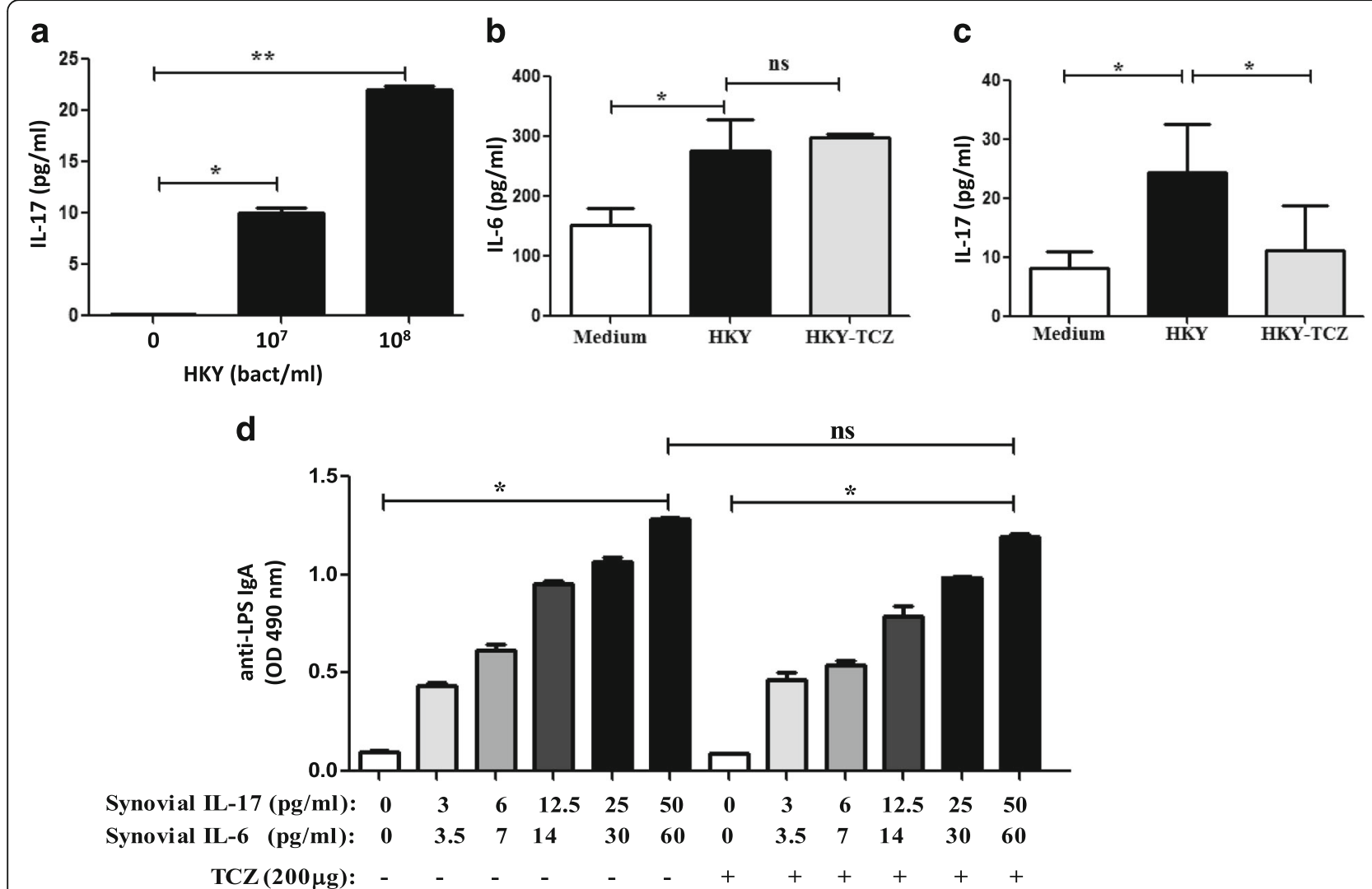

Fig. 2 Association between IL-17 production and IgA anti-enterobacterial antigens. a Dose-dependent IL-17 production in culture supernatants of SF mononuclear cells (SFMC) $\left(2 \times 10^{6}\right.$ cells/well) after $72 \mathrm{~h}$ stimulation with $10^{7}$ or $10^{8}$ bacteria/ml of heat-killed Yersinia (HKY). Concentrations of IL-6 (b) and IL-17 (c) in culture supernatants of SFMC $\left(2 \times 10^{6}\right.$ cells/well) following $72 \mathrm{~h}$ stimulation with $10^{8} \mathrm{HKY}$ with or without tocilizumab (TZC). d Anti-LPS IgA in culture supernatants of SFMC $\left(2 \times 10^{6}\right.$ cells/well) following $96 \mathrm{~h}$ of stimulation with media conditioned with SF containing different concentrations of IL-17 and IL-6 with or without tocilizumab (TZC). Data are expressed as mean \pm SD. ${ }^{*} P<0.05,{ }^{*} P<0.01$

results suggest that IL- 6 mediated IL-17 secretion by enterobacterial antigen in SFMC. To study the influence of IL-17 on the induction of IgA in the joint, we next analyzed anti-LPS IgA in supernatants of SFMC stimulated with media conditioned with different dilutions of SF with high IL-17 and IL-6 concentrations. We found a dose-dependent induction of anti-LPS IgA by IL-17 which could not be inhibited by TCZ (Fig. 2d). Our data suggest that production of IgA specific to enterobacterial antigens is associated with IL-17 levels and that IL- 6 is not essential for IL-17-induced IgA responses.

\section{Interaction of IL-17, TGF- $\beta_{1}$ and BAFF in synovial IgA production}

Since SF recapitulates the microenvironment of joints, we measured anti-enterobacterial IgA in the SF from the patients to correlate the levels of this immunoglobulin with IL-17 concentration. Our results revealed a significant correlation between IL-17 production and anti-LPS IgA antibodies in SF from RA and SpA patients $(r=0.5$; $P<0.01)$ (Fig. 3a). This correlation raised the possibility that IL-17 may contribute to LPS-specific IgA responses.
TGF- $\beta_{1}$ has been shown to have a direct role on class switching to IgA $[19,34,35]$, and we also demonstrated a positive correlation between LPS-specific IgA response and TGF- $\beta_{1}$ levels in SF from RA and SpA patients $(r=$ $0.5 ; P<0.05$ ) (Fig. 3b). Therefore, we explored a possible indirect mechanism by which IL-17 could influence IgA production through TGF- $\beta_{1}$. We detected TGF- $\beta_{1}$ induction in SFMCs stimulated with medium conditioned with different SF containing IL-17 $(20 \mathrm{pg} / \mathrm{ml})$ and undectable TGF- $\beta_{1}$ levels (Fig. 3c). Finally, we found that SF with detectable levels of IL-17 and TGF- $\beta_{1}$ had significantly higher levels of total IgA compared with those with undetectable levels of both cytokines (Fig. 3d). Remarkable, SF containing TGF- $\beta_{1}$ and lacking IL-17 had very low concentration of IgA. However, SF containing IL-17 but lacking TGF- $\beta_{1}$ showed high concentrations of IgA (Fig. 3d). In addition, we analyzed BAFF as this cytokine has been associated with IL-17 in antibody responses [24]. As expected, we observed correlation between BAFF and IgA concentrations in the SF from patients (Fig. 4a). Interestingly, we found significantly higher BAFF levels in SF that were IL-17-positive but 


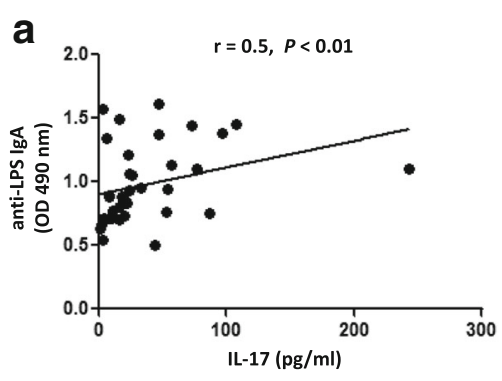

C

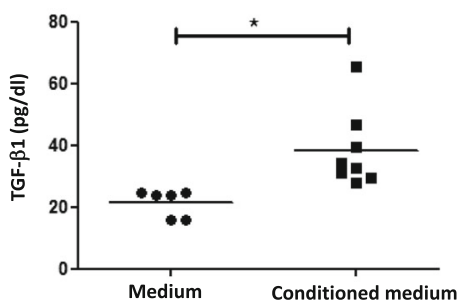

b

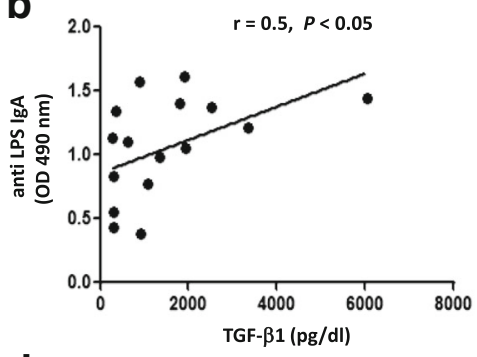

d

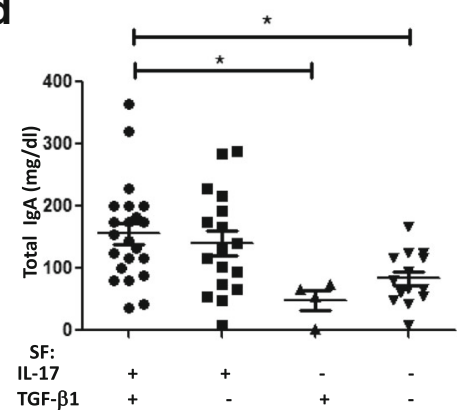

Fig. 3 Interaction of IL-17 and TGF- $\beta_{1}$ for synovial IgA production. Correlation of IL-17 (a) or TGF- $\beta_{1}$ (b) levels with anti-LPS IgA response in SF from patients with RA and SpA (Spearman's rank correlation). c TGF- $\beta_{1}$ production in culture supernatants of SF mononuclear cells (SFMCS) $(2 \times$ $10^{6}$ cells/well) following $96 \mathrm{~h}$ of stimulation with medium conditioned with different SF containing $\mathrm{IL}-17$ ( $\left.20 \mathrm{pg} / \mathrm{ml}\right)$. d Total IgA concentrations in SF with IL-17 and TGF- $\beta_{1}$ in detectable (+) or undetectable (-) levels. Bars show the mean.* $P<0.05$

TGF- $\beta_{1}$-negative ${ }^{-}$(Fig. 4b). In addition, anti-IL-17 decreased TGF- $\beta_{1}$ (Fig. 5a) and anti-LPS IgA (Fig. 5b) in the supernatants of SFMC stimulated with SF, supporting the role of IL-17 contained in the SF on the production of TGF- $\beta_{1}$ and anti-LPS IgA by IL-17 sensitive cells in SFCM. In summary, these data suggest that in the joint microenvironment IL-17 functions to induce synovial IgA in association with TGF- $\beta_{1}$ and BAFF.

\section{Discussion}

The role of IL-17 in the induction of IgA in the joint is poorly understood. Most of the available information on the association between Th17 and IgA comes from studies of intestinal immunity. In this regard, recent studies have demonstrated that $T_{H} 17$ cells are the $T$ helper subset responsible for promoting the $\mathrm{B}$ cell switch toward the production of high-affinity $\mathrm{T}$ cell-dependent IgA responses [36]. Moreover, microbial-specific Th17 cells contribute to intestinal homeostasis by regulating intestinal pIgR expression and IgA secretion [4]. In the present work we focused on IL-17-mediated induction of IgA production in the joint.

First, we detected elevated IL-17 concentrations in SF from both RA and SpA patients compared with control OA patients. These observations are in accordance with previous studies in RA and in SpA [6,32,33] patients. Furthermore, differences in SF concentrations of IL-6 and TGF- $\beta_{1}$ were similar to those found for IL-17, and positive
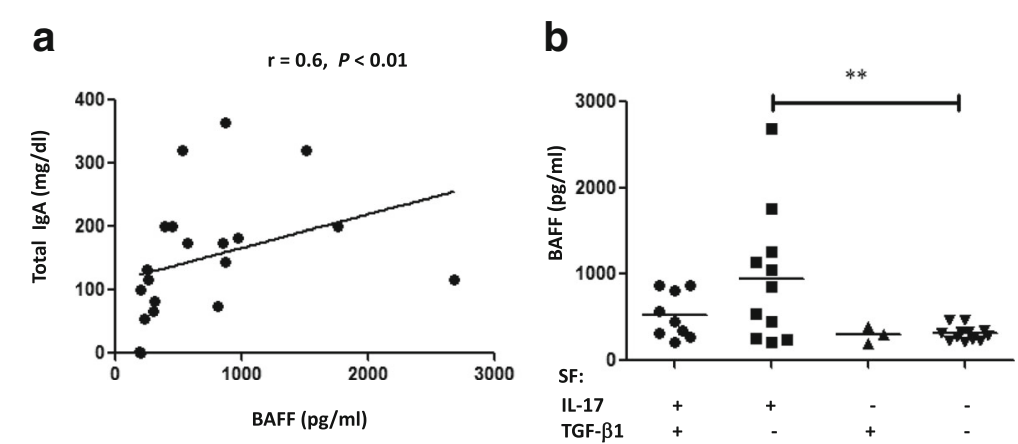

Fig. $4 \mathrm{IL}-17$ and BAFF association for synovial IgA production. a Correlation between BAFF and total IgA concentrations in synovial fluids (SF) from the patients (Spearman's rank correlation). b BAFF concentrations in SF with IL-17 and TGF- $\beta_{1}$ in detectable (+) or undetectable (-) levels. Bars show the mean. ${ }^{* *} P<0.01$ 

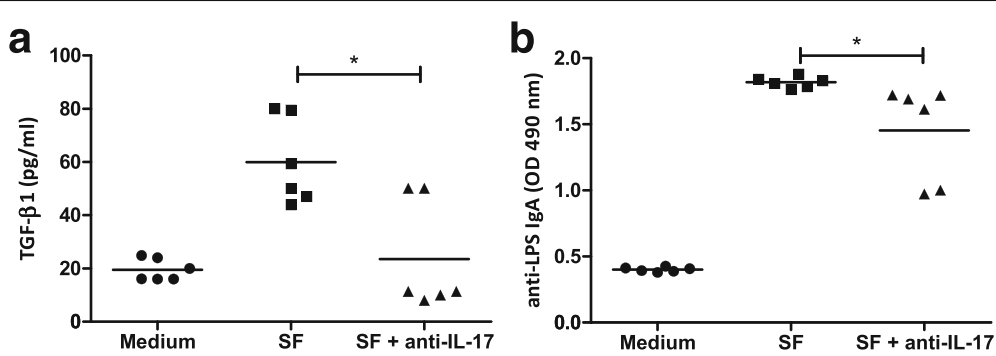

Fig. 5 Blockade of IL-17 decreases the induction of TGF- $\beta_{1}$ and anti-LPS IgA in SF-stimulated SFMCs. TGF- $\beta_{1}(\mathbf{a})$ and anti-LPS IgA (b) in supernatants of SF mononuclear cells (SFMCs) $\left(2 \times 10^{6}\right.$ cells/well) following stimulation with media conditioned with synovial fluid (SF) containing IL-17 in presence of anti-IL-17.*P $<0.05$. Bars show the mean

correlation was also observed between SF concentrations of IL-17 and IL-6. These results are consistent with the role of IL-6 and TGF- $\beta_{1}$ in the differentiation of IL-17-producing $\mathrm{CD}^{+} \mathrm{T}$ cells $[20,21,37]$ and support the involvement of IL-17 in the pathogenesis of the inflammatory arthritis (RA and $\mathrm{SpA}$ ) but not in OA. Noteworthy, we detected a positive association between IL-17 and disease activity evaluated by DAS28 in RA. In accordance, in other study, Th17 cells positively correlated with both CRP levels and DAS28 in RA patients [6]. Although this correlation was more difficult to assess in SpA, accumulating evidence firmly implicates IL-17 in the pathogenesis of SpA [33, 38].

In spite of considerable progress in the elucidation of the relationship between bacterial infection and rheumatologic disorders $[11,12,14]$, the precise mechanism by which bacterial enteroantigens modulate the local inflammatory microenvironment and influence clinical course of inflammatory arthropathies are poorly understood. Here, we found that stimulation with Yersinia antigens promotes robust IL-17 production by SFMC of RA and SpA patients. This induction was IL-6dependent in line with the well-established role of IL-6 as a potent inducer of $\mathrm{T}_{\mathrm{H}} 17$ differentiation [21,37], and the major role of IL-6 in the pathophysiology of arthritis [39]. Additionally, we demonstrated an IL-17-IgA link in the joint since SFMC secreted anti-LPS IgA in response to stimulation with medium conditioned with SF containing different IL-17 concentrations (Fig. 2d). In line with this finding, a relationship between $\mathrm{T}_{\mathrm{H}} 17$ and $\mathrm{B}$ cell differentiation has been identified [40]. In addition, it has been recently reported that lung IgA response is dependent on $\mathrm{T}_{\mathrm{H}} 17$ cells since depletion of IL-17 ablates IgA responses in the lung [41]. Moreover, IL-17 has been involved simultaneously in both aggravating intestinal inflammation and promoting the development of rapidly progressive IgA nephropathy in patients with Crohn's disease [42]. These findings demonstrate a connection between bacterial stimulation, IL-17 and promotion of local IgA response in arthropathies. We found that IL-6 was not essential for IL-17 effects. In line, IL-6 was not required for $\operatorname{IgA}^{+} \mathrm{B}$ cell development or specific mucosal IgA responses in other in vivo systems [43, 44].

We demonstrated that SF with elevated IL-17 and TGF- $\beta_{1}$ levels had higher anti-LPS IgA levels reinforcing $\mathrm{T}_{\mathrm{H}}$ 17-IgA connection in arthritis. TGF- $\beta_{1}$ is a direct regulator of class switching to IgA $[19,45,46]$. Therefore, to investigate whether IL-17 works indirectly for helping the synovial IgA response, we analyzed the relationship between IL-17 and TGF- $\beta_{1}$. Our data indicated that medium conditioned with SF containing IL-17 induced TGF- $\beta_{1}$ production by SFMC. Accordingly, the SF with both cytokines showed the higher levels of IgA in SF. Interestingly, SF containing TGF- $\beta_{1}$ but lacking IL17 showed low IgA concentration suggesting that IL-17 or $\mathrm{T}_{\mathrm{H}} 17$ cytokines may play an essential role for synovial IgA generation. A recent report further demonstrated that $\mathrm{T}_{\mathrm{H}} 17$ cells may convert into $\mathrm{T}$ follicular helper $\left(\mathrm{T}_{\mathrm{FH}}\right)$ cells in Peyer's patches and induce intestinal IgA [3]. It has been shown that IL-21 can modulate B cell differentiation by enhancing TGF- $\beta_{1}$-driven IgA production [46]. Moreover, Cao et al have recently demonstrated that IL-21, produced by both $\mathrm{T}_{\mathrm{H}} 17$ and $\mathrm{T}_{\mathrm{FH}}$ cells, can augment IgA responses mediated by TGF- $\beta_{1}$ and retinoic acid in the intestine, and intestinal sources of IL-21 directly induce IgA production [47]. Therefore, the role of IL-21 in IgA generation in the joint will require further investigation. However, it has been also demonstrated that $\mathrm{T}_{\mathrm{H}} 17$ cell cytokines, IL-17 and IL-21 are able to function indirectly to induce IgA production by promoting the expression of BAFF [47]. In line, our data showed that SF with detectable levels of IL-17 but lacking TGF- $\beta_{1}$ had elevated levels of IgA (Fig. 3d) and BAFF (Fig. 4b). These results indicate alternative promotion of TGF- $\beta_{1}$ and BAFF by IL-17 for synovial IgA generation. Moreover, blockade of IL-17 functions using a specific monoclonal antibody reduced the induction of TGF- $\beta_{1}$ and anti-LPS IgA in SF-stimulated SFMCs. We assume that these findings support again the IL-17 effects on the induction of synovial TGF- $\beta_{1}$ and IgA. Remarkably, IgA concentration has been related with 
active arthritis $[9,10]$, and in the last decade it has become clear that IgA is a very potent stimulus to initiate pro-inflammatory cellular processes [48]. Our study demonstrates the association between IL-17 and IgA responses in the microenvironment of the joint.

\section{Conclusions}

Taken together, our results revealed that combined secretion of IL-17, IL- 6 and TGF- $\beta_{1}$ is a hallmark of inflammatory arthropathies. Moreover, our findings sustain the notion that synovial IL-17 is sensitive to bacterial enteroantigens derived from intestinal infections. These data support an association between IL-17 and IgA responses in the joint, and the involvement of TGF- $\beta_{1}$ and BAFF in the mechanisms of IgA-induction by IL-17.

\section{Abbreviations \\ ACR: American College of Rheumatology; ANOVA: analysis of variance; AS: ankylosing spondylitis; DAS28: 28-joints disease activity score; ESSG: the European Spondyloarthopathy Study Group; ELISA: enzyme-linked immunosorbent assay; HKY: heat killed Yersinia; IBD: inflammatory bowel disease; IgA: immunoglobulin A; IL: interleukin; LPS: lipopolyssacharide; OA: osteoarthritis; PBS: phosphate-buffered saline; PsA: psoriatic arthritis; RA: rheumatoid arthritis; ReA: reactive arthritis; SF: synovial fluids; SFMCs: synovial fluid-derived mono- nuclear cells; SpA: spondyloarthritis; TCZ: tocilizumab; TGF- $\beta_{1}$ : transforming growth factor- $\beta_{1}$; BAFF: B-cell-activating factor of the TNF family; uSpA: undifferentiated SpA}

\section{Acknowledgement}

The authors thank Dr Kapperud (Department of Bacteriology, Oslo, Norway) who kindly provided Yersinia enterocolitica O:8, strain WA-314, and Dr. Adriana Gruppi (National University of Córdoba, Argentina) who provided kindly ELISA kit for BAFF determination.

\section{Funding}

This work was supported by grants from the National Agency for Promotion of Science and Technology (PICT-2008-763, PICT-2011-732), the National University of San Luis (PROICO-2-1114) and Sales Foundation. RJE, MGL, GAR and MSG are members of the Scientific Career of the National Council of Scientific and Technical Investigations (CONICET); JES and MND are postgraduate fellows of CONICET.

\section{Availability of data and materials}

The datasets supporting the conclusions of this article are included within the article.

\section{Authors' contributions}

RJE, JES and MGL performed ELISA, cell culture and data analysis; MND performed ELISA, radial immunodiffusion assay and data analysis; HT, AM and RB collected synovial fluids and performed clinical data gathering; GAR contributed to manuscript preparation and comments; MSDG designed the project, performed ELISA, statistical analysis, data interpretation and manuscript preparation. All authors read and approved the final manuscript.

\section{Competing interests}

The authors declare they have no competing interests.

\section{Consent for publication}

Not applicable.

\section{Ethics approval and consent to participate}

The study was approved by the Ethics Committee of the National University of Cuyo, Mendoza, Argentina. Informed consent was obtained from all patients included in the study. The principles of Helsinki Declaration 1975/ 83 were followed.

\section{Author details}

'Division of Immunology, Faculty of Chemistry, Biochemistry and Pharmacy, National University of San Luis, Ejército de los Andes 950, San Luis, Argentina. ${ }^{2}$ Laboratory of Immunopathology, Multidisciplinary Institute of Biological Investigations - San Luis (IMIBIO-SL), National Council of Scientific and Technical Investigations (CONICET), Ejército de los Andes 950, San Luis 5700, Argentina. ${ }^{3}$ Private Medical Clinic Bolivar, Bolivar 1277, San Luis 5700, Argentina. ${ }^{4}$ Medical Clinic Medici, Ayacucho 1118, San Luis 5700, Argentina. ${ }^{5}$ CENYR Center, Ituzaingo 1074, San Luis 5700, Argentina. ${ }^{6}$ Laboratory of Immunopathology, Institute of Biology and Experimental Medicine (IBYME), CONICET, Vuelta de Obligado 2490, Buenos Aires C1428A, Argentina. ${ }^{7}$ Faculty of Exact and Natural Sciences, University of Buenos Aires, Intendente Güiraldes 2160, Buenos Aires C1428EGA, Argentina.

Received: 18 July 2016 Accepted: 17 January 2017

Published online: 06 February 2017

\section{References}

1. Fagarasan $\mathrm{S}$, Honjo T. Intestinal IgA synthesis: regulation of front line body defences. Nat Rev Immunol. 2003:3:63-72.

2. Hirota $\mathrm{K}$, Ahlfors $\mathrm{H}$, Duarte $\mathrm{JH}$, Stockinger B. Regulation and function of innate and adaptive interleukin-17-producing cells. EMBO Rep. 2012;13:113-20.

3. Hirota K, Turner JE, Villa M, Duarte JH, Demengeot J, Steinmetz OM, Stockinger B. Plasticity of $T_{H} 17$ cells in Peyer's patches is responsible for the induction of T cell-dependent IgA responses. Nat Immunol. 2013;14:372-9.

4. Cao AT, Yao S, Gong B, Elson CO, Cong Y. Th17 cells upregulate polymeric Ig receptor and intestinal IgA and contribute to intestinal homeostasis. J Immunol. 2012;189:4666-73.

5. Maddur MS, Miossec P, Kaveri SV, Bayry J. Th17 Cells: biology, pathogenesis of autoimmune and inflammatory diseases, and therapeutic strategies Am. J Pathol. 2012:181:8-18.

6. Kirkham BW, Kavanaugh A, Reich K. Interleukin-17A: a unique pathway in immune-mediated diseases: psoriasis, psoriatic arthritis and rheumatoid arthritis. Immunobiology. 2014;141:133-42.

7. Granfors K, Toivanen A. IgA-anti-Yersinia antibodies in Yersinia triggered reactive arthritis. Ann Rheum Dis. 1986:45:561-5.

8. Tuuminen T, Kari Lounamo K, Leirisalo-Repo M. A review of serological tests to assist diagnosis of reactive arthritis: critical appraisal on methodologies. Front Immunol. 2013. doi:10.3389/fimmu.2013.00418.

9. Pallavicin FB, Caporali R, Alpini C, Avalle S, Epis OM, Klersy C, Montecucco C. High IgA rheumatoid factor levels are associated with poor clinical response to tumour necrosis factor a inhibitors in rheumatoid arthritis. Ann Rheum Dis. 2007:66:302-7.

10. Franssen MJ, van de Putte LB, Gribnau FW. IgA serum levels and disease activity in ankylosing spondylitis: a prospective study. Ann Rheun Dis. 1985; 44:766-71.

11. Brusca SB, Abramson SB, Scher JU. Microbiome and mucosal inflammation as extra-articular triggers for rheumatoid arthritis and autoimmunity. Curr Opinn Rheumatol. 2014;26:101-7.

12. Moen K, Brun JG, Valen M, Skartveit L, Eribe EK, Olsen I, Jonsson R. Synovial inflammation in active rheumatoid arthritis and psoriatic arthritis facilitates trapping of a variety of oral bacterial DNAs. Clin Exp Rheumatol. 2006;24:656-63.

13. Mcinnes IB, Schett $G$. The pathogenesis of rheumatoid arthritis. N Engl J Med. 2011;365:2205-19.

14. Van Der Heijden IM, Wilbrink B, Tchetverikov I, Schrijver IA, Schouls LM, Hazenberg MP, Breedveld FC, Tak PP. Presence of bacterial DNA and bacterial peptidoglycans in joints of patients with rheumatoid arthritis and other arthritides. Arthritis Rheum. 2000;43:593-8.

15. Dougados M, Baeten MD. Spondyloarthritis. Lancet. 2011:377:2127-37.

16. Van Tubergen A. The changing clinical picture and epidemiology of spondyloarthritis. Nat Rev Rheumatol. 2014:11:110-8.

17. Baeten D, Breban M, Lories R, Schett G, Sieper J. Are spondylarthritides related but distinct conditions or a single disease with a heterogeneous phenotype? Arthritis Rheum. 2013;65:12-20

18. Carter JD, Hudson AP. Reactive arthritis: clinical aspects and medical management. Rheum Dis Clin North Am. 2009;35:21-44.

19. Kim PH, Kagnoff MF. Transforming growth factor beta 1 increases IgA isotype switching at the clonal level. J Immunol. 1990;145:3773-8.

20. Manel N, Unutmaz D, Littman DR. The differentiation of human $T(H)-17$ cells requires transforming growth factor-beta and induction of the nuclear receptor RORgammat. Nat Immunol. 2008;9:641-9. 
21. Wilson NJ, Boniface K, Chan JR, McKenzie BS, Blumenschein WM, Mattson JD, Basham B, Smith K, Chen T, Morel F, Lecron JC, Kastelein RA, Cua DJ, McClanahan TK, Bowman EP, de Waal Malefyt R. Development, cytokine profile and function of human interleukin 17-producing helper T cells. Nat Immunol. 2007;8:950-7.

22. Hilbert DM, Cancro MP, Scherle PA, Nordan RP, Van Snick J, Gehard W, Rudikoff S. T cell derived IL-6 is differentially required for antigen-specific antibody secretion by primary and secondary B cells. J Immunol. 1989;143:4019-24.

23. Litinskiy MB, Nardelli B, Hilbert DM, He B, Schaffer A, Casali P, Cerutti A. DCs induce CD40-independent immunoglobulin class switching through BLyS and APRIL. Nat Immunol. 2002;3:822-9.

24. Doreau A, Belot A, Bastid J, Riche B, Trescol-Biemont MC, Ranchin B, Fabien N, Cochat P, Pouteil-Noble C, Trolliet P, Durieul TJ, Kassai B, Ansieau S, Puisieux A, Eliaou JF, Bonnefoy-Bérard N. Interleukin 17 acts in synergy with $B$ cell-activating factor to influence B cell biology and the pathophysiology of systemic lupus erythematosus. Nat Immunol. 2009;10:778-85.

25. Arnett FC, Edworthy SM, Bloch DA, McShane DJ, Fries JF, Cooper NS, Healey LA, Kaplan SR, Liang MH, Luthra HS, et al. The American Rheumatism Association 1987 revised criteria for the classification of rheumatoid arthritis. Arthritis Rheum. 1988;31:315-24.

26. Dougados M, Van Der Linden S, Juhlin R, Huitfeldt B, Amor B, Calin A, Cats A, Dijkmans B, Olivieri I, Pasero G, et al. The European Spondyloarthropathy Study Group preliminary criteria for the classification of spondyloarthropathy. Arthritis Rheum. 1991;34:1218-27.

27. Balsa A, Carmona L, Gonzalez-Alvaro I, Belmonte MA, Tena X, Sanmarti R, EMECAR Study Group. Value of Disease Activity Score 28 (DAS28) and DAS28-3 compared to American College of Rheumatology-defined emission in rheumatoid arthritis. J Rheumatol. 2004;31:40-6.

28. Cohen AS, Goldenberg D. Synovial fluid. In: Cohen AS, editor. Laboratory diagnostic procedures in the rheumatic diseases. Orlando: Grune \& Stratton; 1985. p. 40-53.

29. Kortekangas P, Aro HT, Tuominen J, Toivanen A. Synovial fluid leukocytosis in bacterial arthritis vs. reactive and rheumatoid arthritis in the adult knee. Scand J Rheumatol. 1992;21:283-8.

30. Di GenaroM S, MuñozE AC, de Guzmán AMS. Yersinia enterocolitica O:8 and 0:5 lipopolysaccharide arthritogenicity in hamsters. Rheumatology. 2000;39:73-8.

31. Frey N, Grange S, Woodworth T. Population pharmacokinetic analysis of tocilizumab in patients with rheumatoid arthritis. J Clin Pharmacol. 2010;50:754-66.

32. Ziolkowska M, Koc A, Luszczykiewicz G, Ksiezopolska-Pietrzak K, Klimczak E, Chwalinska-Sadowska H, Maslinski W. High levels of IL-17 in rheumatoid arthritis patients: IL-15 triggers in vitro IL-17 production via cyclosporin Asensitive mechanism. J Immunol. 2000;164:2832-8.

33. Singh AK, Misra R, Aggarwal A. Th-17 associated cytokines in patients with reactive arthritis/undifferentiated spondyloarthropathy. Clin Rheumatol. 2011;30: 771-6.

34. Jang YS, Seo GY, Lee JM, Seo HY, Han HJ, Kim SJ, Jin BR, Kim HJ, Park SR, Rhee KJ, Kim WS, Kim PH. Lactoferrin causes IgA and IgG2b isotype switching through betaglycan binding and activation of canonical TGF[beta] signaling. Mucosal Immunol. 2015;8:906-17.

35. Roy B, Brennecke AM, Agarwal S, Krey M, Duber S, Weiss S. An intrinsic propensity of murine peritoneal B1b cells to switch to IgA in presence of TGF-beta and retinoic acid. PLoS One. 2013;8, e82121.

36. Milpied $P$, Mcheyzer-Williams $M$. High-affinity $\lg A$ needs $T_{H} 17$ cell functional plasticity. Nat Immunol. 2013;14:313-5.

37. Bettelli E, Korn T, Oukka M, Kuchroo VK. Induction and effector functions of TH17 cells. Nature. 2008;453:1051-7.

38. Smith JA, Colbert RA. The interleukin-23/Interlukin-17 axis in spondyloarthritis pathogenesis. Arthritis Rheum. 2014;66:231-41.

39. Liang B, Song Z, Wu B, Gardner D, Shealy D, Song XY, Wooley PH. Evaluation of anti-IL-6 monoclonal antibody therapy using murine type II collagen-induced arthritis. J Inflamm (Lond). 2009;6:10. doi:10.1186/1476-9255-6-10.

40. Barbosa RR, Silva SP, Silva SL, Melo AC, Pedro E, Barbosa MP, Pereira-Santos MC, Victorino RM, Sousa AE. Primary B-Cell deficiencies reveal a link between human IL-17-producing CD4 T-cell homeostasis and B-Cell differentiation. PLoS One. 2011;6, e22848. doi:10.1371/journal.pone.0022848.

41. Christensen D, Mortensen R, Rosenkrands I, Dietrich J, Andersen P. Vaccineinduced Th17 cells are established as resident memory cells in the lung and promote local IgA responses. Mucosal Immunol. 2016; doi:10.1038/mi.2016.28.

42. Choi JY, Yu CH, Jung HY, Jung MK, Kim YJ, Cho JH, Kim CD, Kim YL, Park SH. A case of rapidly progressive IgA nephropathy in a patient with exacerbation of Crohn's disease. BMC Nephrol. 2012; doi:10.1186/1471-236913-84.
43. Bromander AK, Ekman L, Kopf M, Nedrud JG, Lycke NY. IL-6-deficient mice exhibit normal mucosal IgA responses to local immunizations and Helicobacter felis infection. J Immunol. 1996;156:4290-7.

44. Beagley KW, Bao S, Ramsay AJ, Eldridge JH, Husband AJ. IgA production by peritoneal cavity B cells is IL-6 independent: implications for intestinal $\lg A$ responses. Eur J Immunol. 1995;25:2123-6.

45. Cazac BB, Roes J. TGF- $\beta$ receptor controls B cell responsiveness and induction of IgA in vivo. Immunity. 2000;13:443-51.

46. Seo GY, Youn J, Kim PH. IL-21 ensures TGF-beta 1-induced IgA isotype expression in mouse Peyer's patches. J Leukoc Biol. 2009;85:744-50.

47. Cao AT, Yao S, Gong B, Nurieva RI, Elson CO, Cong Y. Interleukin (IL)-21 promotes intestinal IgA response to microbiota. Mucosal Immunol. 2015;8: 1072-82.

48. Aleyd E, Heineke MH, van Egmond MT. The era of the immunoglobulin A Fc receptor FcaRl; its function and potential as target in disease. Immunol Rev. 2015;268:123-38.

\section{Submit your next manuscript to BioMed Central and we will help you at every step:}

- We accept pre-submission inquiries

- Our selector tool helps you to find the most relevant journal

- We provide round the clock customer support

- Convenient online submission

- Thorough peer review

- Inclusion in PubMed and all major indexing services

- Maximum visibility for your research

Submit your manuscript at www.biomedcentral.com/submit

) Biomed Central 